JAMP: Jurnal Adminitrasi dan Manajemen Pendidikan

Volume 1 Nomor 4 Desember 2018, Hal : 400-409

Tersedia Online di http://journal2.um.ac.id/index.php/jamp/

ISSN 2615-8574 (online)

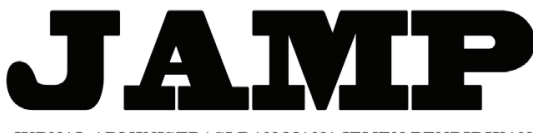

JURNAL ADMINISTRASI DAN MANAJEMEN PENDIDIKAN

\title{
HUBUNGAN ANTARA KEPUASAN KERJA, KOMPETENSI, DAN KINERJA GURU
}

\author{
Ismaya Priska Kumala \\ Burhanuddin \\ Ibrahim Bafadal
}

ismayapriskak@gmail.com

Universitas Negeri Malang, Jalan Semarang 5, Malang 65145

\begin{abstract}
The purpose of the research was to describe relationships between job satisfaction, competencies, and teacher performance at Vocational High School in Batu City. The study was descriptive in nature employing multiple correlational design. The population of this study are all teachers at this school and a sample was selected using simple random sampling. Data were analyzed employing analytical descriptive technique and multiple correlation. Results of the study indicate that there is a relationship between job satisfaction and performance, and there is a multiple relationship between the components of competencies, job satisfaction, and performance.
\end{abstract}

Keywords: Job satisfaction, competencies, performance

\begin{abstract}
Abstrak: penelitian ini bertujuan untuk mendeskripsikan hubungan antara kepuasan kerja, kompetensi, dan kinerja Guru di SMK Kota Batu. Penelitian menggunakan pendekatan deskriptif dengan desain korelasi ganda. Populasi penelitian ini adalah semua guru di SMK Batu. Sampel ditentukan menggunakan teknik simple random sampling. Data dianalisis menggunakan teknik deskriptif dan korelasi ganda. Hasil penelitian menunjukkan bahwa terdapat hubungan antara kepuasan kerja dan kinerja. Di samping itu ditemukan hubungan antar komponen variabel meliputi kompetensi, kepuasan kerja, dan kinerja Guru di SMK Kota Batu.
\end{abstract}

Kata kunci: Kepuasan kerja, kompetensi, kinerja.

Kinerja guru merupakan salah satu faktor penentu tercapainya tujuan pendidikan. Kinerja guru bisa tinggi jika kompetensi yang dimiliki guru juga memadai, sehingga menghasilkan kepuasan kerja yang tinggi pula. Tingkat kepuasan guru dapat berdampak pada kinerja seorang guru, dan terhadap lembaga pendidikan tempat dia bekerja. Guru adalah sumber daya sentral dalam pendidikan. Untuk dapat meraih kinerja yang baik itu, maka guru-guru harus mampu menguasai berbagai kompetensi yang diperlukan dalam mendukung pencapain tujuan pendidikan di sekolah. Kinerja guru dipengaruhi oleh penguasaan kompetensi meliputi: pedagogik, kepribadian, sosial, dan profesional (Permendiknas Nomor 16 Tahun 2007). Sehubungan dengan ini Mangkunegara (2009) mengemukakan beberapa faktor yang dapat mempengaruhi kinerja adalah faktor kemampuan dan motivasi. Faktor-faktor ini perlu dipertimbangkan dalam pembinaan guru agar mereka dapat memperoleh kepuasan atas hasil yang dicapai. Robbins (1996) menyebutkan sejumlah faktor yang mempengaruhi kepuasan kerja, yaitu: (a) pekerjaan yang sifatnya menantang; (b) gaji atau upah yang pantas; (c) kondisi kerja; dan (d) sejawat yang mendukung. Di samping itu guru perlu mendemonstrasikan kinerja tinggi sehingga diharapkan dapat meningkatkan kepuasan kerja. Meskipun demikian, hasil studi terdahulu menunjukkan 
bahwa masih terdapat penguasaan kompetensi yang kurang memadai sehingga berdampak negatif terhadap kinerja guru-guru.

Hasil penilaian di Kota Batu menunjukkan bahwa para guru di Kota Batu terlalu sibuk dengan urusan administratif seperti upaya melengkapi persyaratan sertifikasi dan angka kredit. Hal ini menyebabkan menurunnya intensitas pembelajaran, sehingga hasil belajar siswa tidak maksimal. Di Kota Batu, angka ketidaklulusan Ujian Nasional SMP tergolong tinggi. Dari 2.010 peserta, ada sebanyak 580 siswa atau 28.8 persen yang tidak lulus. Untuk Madrasah (MTs), tingkat ketidaklulusannya mencapai 25,82 persen atau 364 siswa dari total 1.410 siswa. Sedangkan untuk SMA, tingkat kelulusannya hanya 80,97 persen atau 19,03 persen peserta yang tidak lulus, dan untuk tingkat kelulusan SMK sebesar 70,12 persen atau dari 810 siswa SMK yang mengikuti ujian, terdapat 242 siswa yang tidak lulus. Berdasarkan rasionalisasi tersebut, membuktikan bahwa jika kompetensi yang kurang memadai akan berdampak pada kinerja guru yang kurang memadai pula, sehingga guru merasa kurang puas dengan pekerjaan yang diemban.

Kinerja atau prestasi kerja adalah perolehan kerja seorang pegawai sesuai dengan tujuan organisasi. Kinerja dapat didefinisikan sebagai segala proses yang dapat menguntungkan organisasi di antaranya terdapat visi, misi, dan tujuan dari sebuah organisasi yang menghasilkan kuantitas dan kualitas, daya cipta, kemudahan dan kecepatan dalam penyesuaian diri (Brahmasari, 2008). Di samping itu definisi kinerja adalah kemampuan dan keinginan pegawai, kemampuan dan alasan yang logis atas terpilihnya sebagai pegawai yang mampu mengerjakan suatu pekerjaan, dan tinggi rendahnya motivasi atau tujuan, gabungan dari ketiga faktor tersebut menghasilkan suatu kinerja atau prestasi kerja (Hasibuan, 2007). Hasil yang didapat dari pegawai disebut sebagai kinerja atau performance (Shadily, 1992). Glickman (dalam Bafadal, 2003) menegaskan bahwa seseorang akan bekerja secara profesional bilamana orang tersebut memiliki kemampuan (ability) dan motivasi (motivation). Maksudnya adalah seseorang akan bekerja secara profesional bilamana memiliki kemampuan kerja yang tinggi dan motivasi untuk mengerjakan dengan sebaik-baiknya. Sebaliknya, seseorang tidak akan bekerja secara profesional bilamana hanya memenuhi salah satu persyaratan saja, jadi betapapun tingginya kemampuan seseorang, ia tidak akan bekerja secara profesional apabila tidak memiliki motivasi kerja yang tinggi.

Kompetensi didefinisikan sebagai suatu kolaborasi atau hasil kerja sama antara bakat dan kemampuan yang dimiliki seseorang (Robbins \& Judge, 2007). Cara belajar yang dimiliki pribadi satu sama lain akan berbeda dan terlihat unik sesuai dengan yang diharapkan. Setiap individu memiliki kapasitas yang berbeda-beda untuk dapat menyelesaikan segala pekerjaan, itu sebabnya kemampuan yang satu dengan yang lainnya bervariasi. Kolaborasi antara pengetahuan dan keterampilan akan menghasilkan sebuah kemampuan. Menurut penelitian Robbins (2007) kompetensi juga dapat didefinisikan sebagai perpaduan antara kemampuan berpikir dan kemampuan fisik yang mempengaruhi besar kecilnya hasil seseorang dalam menyelesaikan berbagai tugas dalam satu waktu. Kompetensi ialah sekumpulan kecakapan yang menunjukkan karakteristik seimbang untuk mengerjakan berbagai tugas dalam satu waktu sehingga hasil kerja tersebut memiliki nilai. Ini menjadi keharusan guru melihat begitu pentingya pula kompetensi karena berhubungan langsung oleh kinerja guru di sekolah. Selain faktor kompetensi, terdapat faktor yang berhubungan kinerja guru, yaitu kepuasan kerja. Karena jika kinerja guru tinggi maka kompetensi juga tinggi, sehingga perasaan puas tinggi dalam mengerjakan pekerjaan. Untuk lebih jelasnya, memaparkan tentang kepuasan kerja.

Kepuasan kerja didefinisikan sebagai bentuk hadiah atau penghasilan yang diterima oleh seseorang dibandingkan dengan kinerjanya (Robbins, 2003). Kepuasan kerja bisa juga didefinisikan sebagai situasi dan kondisi yang dialami oleh karyawan baik disukai atau tidak dengan hasil yang diperoleh (Handoko, 2000). Di samping itu kepuasan kerja didefinisikan sebagai turnover atau pergantian karyawan, ketidakhadiran, dan kelancaran promosi (Mangkunegara, 2005). Menurut Siagian (2013) kepuasan kerja merupakan suatu perspektif positif dan negatif seseorang berkenaan dengan pekerjaan. Selain itu, Luthans (2006) berpendapat kepuasan kerja adalah perihal emosional berasal dari penilaian pekerjaan yang dialami. Menurut De Roche (dalam Burhanuddin, Imron, \& Maisyaroh (2009) kepuasan kerja guru perlu diperhatikan karena sebagai pengakuan yang sangat berharga bagi guru. Pada dasarnya guru mengharapkan kebutuhan dasar mereka terpenuhi. Jika profesi dan prestasinya diakui, maka guru merasa kebutuhan dasarnya terpenuhi. 
Terdapat hubungan antara kompetensi guru dengan kinerja guru, dan hubungan antara kecerdasaran emosional dengan kinerja guru. Semakin tinggi kinerja guru semakin tinggi pula kompetensi dan kecerdasan emosional guru (Wahyuddin, 2016). Sementara Herman (2011) menyimpulkan bahwa ada pengaruh positif dan signifikan antara kompetensi profesional Guru terhadap Kinerja Guru sebanyak 26,8\%. Penelitian oleh Chamundeswari (2013) memperoleh hasil kepuasan kerja dan kinerja guru berkorelasi signifikan dan positif satu sama lain. Penelitian oleh Baroroh (2013) menunjukkan ada hubungan positif yang sangat signifikan antara kepuasan kerja dengan kinerja karyawan yang artinya semakin tinggi kepuasan kerja maka semakin tinggi pula tingkat kinerja karyawan. Penelitian oleh Setyoningsih (2015) memperoleh hasil penelitian terdapat hubungan positif dan sagat signifikan antara kepuasan kerja dengan kinerja guru rxy=0,612 dan siginifikansi $<0,01$. Penelitian Tentama (2015) memperoleh hasil berupa terdapat korelasi positif yang sangat signifikan antara kepuasan kerja dengan kinerja pada guru PNS ( $\mathrm{rxy}=0,551 ; \mathrm{p}=0,001)$ artinya semakin tinggi kepuasan kerja maka semakin tinggi kinerja guru, begitu juga sebaliknya. Selanjutnya penelitian oleh Arifin (2014) memperoleh hasil terdapat pengaruh secara positif dan signifikan antara kompetensi terhadap kinerja guru, maksudnya jika kompetensi tinggi dapat meningkatkan kinerja guru. Kemudian terdapat pengaruh positif dan signifikan antara kepuasan kerja dengan kinerja, berarti kepuasan kerja yang tinggi akan membuat kinerja juga lebih tinggi.

Salah satu aspek untuk melihat keberhasilan pendidikan dapat didasarkan pada guru sebagai pendidik menjalankan tugas utamanya sesuai dengan kompetensi yang harus dimiliki sehingga kinerja menjadi maksimal, dan merasakan kepuasan atas hasil yang telah dilakukan, bukan hanya untuk mengikuti sertifikasi. Dilihat dari situasi dan kondisi pendidikan di Kota Batu, beberapa penelitian terdahulu dan faktor-faktor yang mempengaruhi dari ketiga variabel, peneliti merasa mampu, penting, perlu, dan tertarik mendeskripsikan hubungan antara kepuasan kerja, kompetensi dan kinerja Guru di SMK Kota Batu. Melihat banyaknya penelitian terdahulu, terdapat beberapa persamaan dan perbedaan. Persamaan pada kepuasan kerja dan kinerja. Perbedaan penelitian berada di lokasi penelitian dan tujuan penelitian, di mana bertujuan untuk menemukan tingkat kepuasan kerja guru, tingkat kompetensi guru, dan tingkat kinerja guru.

Berdasarkan kajian tersebut, hipotesis penelitian ini dirumuskan: (1) terdapat hubungan antara kepuasan kerja dan kinerja Guru di SMK Kota Batu, (2) terdapat hubungan antara kompetensi dan kinerja Guru di SMK Kota Batu, (3) terdapat hubungan antara kepuasan kerja dan kompetensi Guru di SMK Kota Batu.

\section{METODE}

Penelitian menggunakan pendekatan deskriptif dengan desain korelasi ganda. Model ini diterapkan untuk mengetahui ada tidaknya hubungan antara variabel kepuasan kerja (X1), kompetensi (X2), dan kinerja (Y). Populasi penelitian adalah semua guru di SMK Kota Batu yang berjumlah 343 orang. Sampel sejumlah 185 orang dipilih menggunakan teknik simple random sampling. Data penelitian dikumpulkan menggunakan kuesioner dengan Skala Likert yang menyediakan empat alternatif jawaban: (1) SS/SL, (2) S/SR, (3) TS/JR, (4) STS/TP.

Uji validitas menggunakan analisis faktor dengan teknik Principle Component Analysis Uji reliabilitas menggunakan Alpha Cronbach. Data dianalisis menggunakan teknik deskriptif dan korelasi ganda. Tahap-tahap analisis meliputi: (1) analisis data deskriptif dengan menentukan panjang kelas interval, menentukan persentase, dan mencari mean, (2) uji normalitas dan linearitas, (3) analisis korelasi pearson product moment, dan (4) analisis korelasi ganda.

\section{HASIL}

Hasil penelitian ini dibagi ke dalam dua bagian yaitu hasil deskriptif dan pengujian hipotesis. Hasil analisis deskriptif dari kepuasan kerja, kompetensi, dan kinerja Guru di SMK Kota Batu disajikan dalam Tabel 1, 2, 3, dan 4 . 
Variabel kepuasan kerja (X1) dijabarkan menjadi 24 indikator yang termuat oleh 56 item pernyataan. Setiap butir pernyataan skor tertinggi yang diperoleh adalah 56 x $4=224$, dan skor terendah sebesar $56 \times 1=56$. Tingkat kepuasan kerja dibagi menjadi empat golongan yaitu sangat tinggi, tinggi, rendah, dan sangat rendah. Untuk menentukan tingkat tersebut, maka perlu diketahui panjang kelas interval dari variabel (X1). Penghitungan panjang kelas interval menggunakan rumus di bawah ini:

$$
\begin{aligned}
& \text { Panjang Kelas Interval }=\frac{\text { Skor Tertinggi }- \text { Skor Terendah }}{\text { Banyak Kelas Interval }} \\
& \begin{aligned}
& \text { Panjang Kelas Interval }=\frac{(57 \times 4)-(57 \times 1)}{4}=\frac{228-57}{4}=42,75 \\
&=43
\end{aligned}
\end{aligned}
$$

Berdasarkan hasil perhitungan panjang kelas interval di atas, maka mendapatkan hasil perhitungan untuk menentukan kualifikasi dan interval nilai dari variabel X1 disajikan Tabel 1.

Tabel 1 Kualifikasi dan Interval Nilai (X1)

\begin{tabular}{ccccccc}
\hline No & $\begin{array}{c}\text { Alternatif } \\
\text { Jawaban }\end{array}$ & Kode & Interval & Kategori & Frekuensi & Persentase \\
\hline 1. & SS & 4 & $185-227$ & Sangat Tinggi & 42 & 22.7 \\
2. & S & 3 & $142-184$ & Tinggi & 137 & 74.1 \\
3. & TS & 2 & $99-141$ & Rendah & 6 & 3.2 \\
4. & STS & 1 & $56-98$ & Sangat Rendah & 0 & 0 \\
& \multicolumn{2}{c}{ TOTAL } & & 185 & 100.0 \\
\hline
\end{tabular}

Sumber: Data Diolah SPSS (2018).

Berdasarkan Tabel 1 di atas bahwa dari 185 responden, 42 orang Guru (22.7\%) menunjukkan tingkat kepuasan kerja terhadap kinerja sangat tinggi. Terdapat 137 orang guru $(74.1 \%)$ responden mendapatkan hasil kepuasan kerja yang dimiliki guru terhadap kinerja berada dalam kualifikasi tinggi, 6 Guru (3.2\%) responden mendapatkan hasil kepuasan terhadap kinerja rendah, dan tidak ada responden yang mendapatkan hasil sangat rendah terkait kepuasan kerja yang dimiliki oleh Guru dalam kinerja. Kemudian nilai mean kepuasan kerja adalah170.61 berada pada interval 142-184 tergolong kategori tinggi. Untuk tampilan deskripsi kualifikasi dan interval nilai X1 dapat dilihat pada Gambar 1.

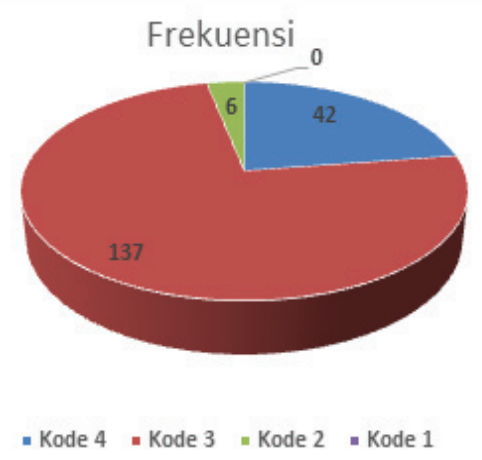

Gambar 1. Kualifikasi dan Interval Nilai (X1)

Variabel kompetensi (X2) dijabarkan menjadi 24 indikator yang terbagi menjadi 55 item pernyataan. Setiap butir pernyataan mempunyai skor tertinggi yang diperoleh yaitu 55 x $4=220$, dan skor terendah yaitu $55 \times 1=55$. Tingkat kompetensi dibagi menjadi empat golongan yaitu sangat tinggi, tinggi, rendah, dan sangat rendah. Untuk menentukan tingkat tersebut, maka perlu diketahui panjang kelas interval dari variabel (X2). Penghitungan panjang kelas interval menggunakan rumus di bawah ini:

$$
\begin{gathered}
\text { Panjang Kelas Interval }=\frac{\text { Skor Tertinggi }- \text { Skor Terendah }}{\text { Banyak Kelas Interval }} \\
\text { Panjang Kelas Interval }=\frac{(55 \times 4)-(55 \times 1)}{4}=\frac{220-55}{4}=41,25
\end{gathered}
$$$$
=41
$$ 
Berdasarkan hasil perhitungan panjang kelas interval di atas, maka mendapatkan hasil perhitungan untuk menentukan kualifikasi dan interval nilai dari variabel X2 ditampilkan Tabel 2.

Tabel 2 Kualifikasi dan Interval Nilai (X2)

\begin{tabular}{ccccccc}
\hline No & $\begin{array}{c}\text { Alternatif } \\
\text { Jawaban }\end{array}$ & Kode & Interval & Kategori & Frekuensi & Persentase \\
\hline 1. & SS & 4 & $181-222$ & Sangat Tinggi & 68 & 36.8 \\
2. & S & 3 & $139-180$ & Tinggi & 117 & 63.2 \\
3. & TS & 2 & $97-138$ & Rendah & 0 & 0 \\
4. & STS & 1 & $55-96$ & Sangat Rendah & 0 & 0 \\
& \multicolumn{2}{c}{ TOTAL } & & 185 & 100.0 \\
\hline
\end{tabular}

Sumber: Data Diolah SPSS (2018).

Berdasarkan Tabel 2, dari 185 responden, 68 guru (36.8\%) penguasaan kompetensi yang dimiliki oleh guru tinggi. Kinerja berada dalam kualifikasi sangat tinggi. Di samping itu, 117 Guru (63.2\%) memiliki tingkat puasan kerja yang tinggi. Mengenai penguasaan kompetensi, tidak ada responden yang memiliki nilai dalam kategori rendah-sangat rendah. Tidak ada satu respondenpun yang menyatakan rendah - sangat rendah terhadap kompetensi yang dimiliki oleh guru. Nilai mean kompetensi adalah 177,70 berada pada interval 139-180 berarti tergolong dalam kategori tinggi. Untuk tampilan deskripsi kualifikasi dan interval nilai X2 dapat diperksa Gambar 2.

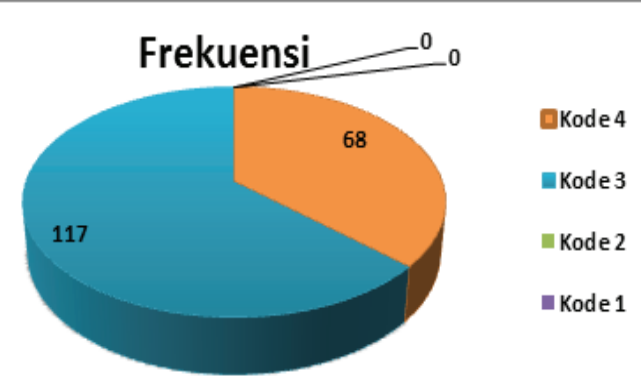

Gambar 2 Kualifikasi dan Interval Nilai (X2)

Variabel Kinerja (Y) dijabarkan menjadi 9 indikator yang terbagi menjadi 21 item pernyataan. Setiap butir pernyataan memiliki skor tertinggi yang diperoleh yaitu $21 \times 4=84$, dan skor terendah 21 $\mathrm{x} 1=21$. Tingkat kinerja dibagi menjadi empat golongan, yaitu sangat tinggi, tinggi, rendah, dan sangat rendah. Untuk menentukan tingkat tersebut, maka perlu diketahui panjang kelas interval dari variabel (Y). Penghitungan panjang kelas interval menggunakan rumus di bawah ini:

$$
\begin{aligned}
& \text { Panjang Kelas Interval }=\frac{\text { Skor Tertinggi }- \text { Skor Terendah }}{\text { Banyak Kelas Interval }} \\
& \begin{array}{c}
\text { Panjang Kelas Interval } \\
=16
\end{array} \quad \begin{array}{c}
(21 \times 4)-(21 \times 1) \\
4
\end{array}=\frac{84-21}{4}=15,75
\end{aligned}
$$

Berdasarkan hasil perhitungan panjang kelas interval di atas, maka mendapatkan hasil perhitungan untuk menentukan kualifikasi dan interval nilai dari variabel Y. Dapat dilihat pada Tabel 3.

Berdasarkan Tabel 3 mendapatkan hasil dari 185 responden, 50 Guru (27.0\%) responden kinerja yang dimiliki oleh Guru berada dalam kualifikasi sangat tinggi, 131 Guru $(70.8 \%)$ responden kinerja yang dimiliki Guru berada dalam kualifikasi tinggi, dan sebanyak 4 Guru (2.2\%) responden kinerja yang dimiliki Guru berada dalam kualifikasi rendah, serta tidak ada responden yang menyatakan sangat rendah terkait kinerja yang dimiliki oleh Guru. Kemudian nilai mean kinerja yaitu 66,53 berada pada interval 55-71 berada pada kategori tinggi. Untuk tampilan deskripsi kualifikasi dan interval nilai Y dapat dilihat pada Gambar 3. 
Tabel 3 Kualifikasi dan Interval Nilai (Y)

\begin{tabular}{ccccccc}
\hline No & $\begin{array}{c}\text { Alternatif } \\
\text { Jawaban }\end{array}$ & Kode & Interval & Kategori & Frekuensi & Persentase \\
\hline 1. & SS & 4 & $72-88$ & Sangat Tinggi & 50 & 27.0 \\
2. & S & 3 & $55-71$ & Tinggi & 131 & 70.8 \\
3. & TS & 2 & $38-54$ & Rendah & 4 & 2.2 \\
4. & STS & 1 & $21-37$ & Sangat Rendah & 0 & 0 \\
& \multicolumn{2}{c}{ TOTAL } & & 185 & 100.0 \\
\hline
\end{tabular}

Sumber: Data Diolah SPSS (2018).

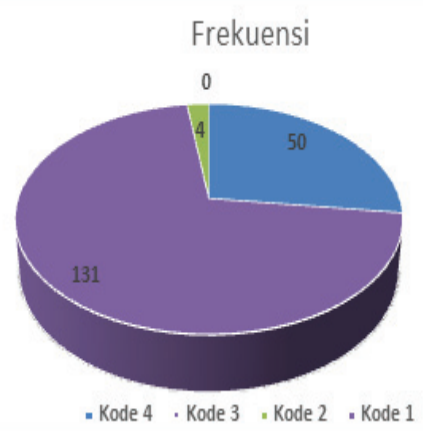

Gambar 3 Kualifikasi dan Interval Nilai (Y)

Pengujian hipotesis dilakukan untuk tiga hipotesis penelitian. Hasil hipotesis diuraikan secara berurutan sebagai berikut.

\section{Pengujian Hipotesis 1}

Hasil uji statistik menunjukkan H0 ditolak, berarti ada hubungan signifikan antara kepuasan kerja dan kinerja guru. Hasil analisis korelasi TOTAL (X1 kepuasan kerja) memperoleh koefisien sebesar 0,597 dengan tingkat signifikansi $<0,05$. Ini menunjukkan H0 ditolak, sehingga dapat diartikan terdapat hubungan signifikan antara kepuasan kerja dengan kinerja guru di SMK Kota Batu.

\section{Pengujian Hipotesis 2}

Hasil uji statistik menunjukkan H0 ditolak, berarti ada hubungan signifikan antara kompetensi dan kinerja guru. Hasil analisis korelasi TOTAL (X2 kompetensi) memperoleh koefisien sebesar 0,853 dengan tingkat signifikansi $<0,05$. Ini menunjukkan H0 ditolak, sehingga dapat diartikan terdapat hubungan signifikan antara kompetensi dengan kinerja guru di SMK Kota Batu.

\section{Pengujian Hipotesis 3}

Hipotesis ketiga membuktikan H0 ditolak, berarti terdapat hubungan signifikan antara kepuasan kerja dan kompetensi guru. Hasil dari analisis korelasi TOTAL (X1 kepuasan kerja) memperoleh koefisien sebesar 0,646 dengan nilai signifikansi $<0,05$. ini menunjukkan H0 ditolak, sehingga dapat diartikan terdapat hubungan signifikan antara kepuasan kerja dengan kinerja guru di SMK Kota Batu.

\section{PEMBAHASAN}

\section{Hubungan antara Kepuasan Kerja dan Kinerja Guru di SMK Kota Batu}

Nilai Pearson Correlation sebesar 0,611 dengan nilai signifikansi $0,000<0,05$ berarti menunjukkan ada hubungan positif signifikan antara kepuasan kerja (X1) dengan kinerja (Y). Temuan ini relevan dengan hasil penelitian Tentama (2015) yakni adanya hubungan positif antara kepuasan kerja dengan kinerja guru. Dengan demikian dapat ditafsirkan bahwa kepuasan kerja memiliki pengaruh yang kuat 
terhadap kinerja. Hasil penelitian sama namun berbeda lokasi yaitu dilakukan oleh Setyoningsih (2015) memperoleh temuan terdapat hubungan positif dan sangat signifikan antara kepuasan kerja dengan kinerja. Semakin tinggi kepuasan kerja maka semakin tinggi kinerja guru, begitu juga sebaliknya. Penelitian lain kembali oleh Chamundeswari (2013) memperoleh hasil kepuasan kerja dan kinerja guru berkorelasi positif dan signifikan satu dengan yang lainnya.

Hasil perhitungan menunjukkan bahwa dari 185 responden, 42 Guru (22.7\%) responden menyatakan bahwa kepuasan kerja yang dimiliki oleh Guru terhadap kinerja berada dalam kualifikasi sangat tinggi, 137 Guru (74.1\%) responden menyatakan bahwa kepuasan kerja yang dimiliki Guru terhadap kinerja berada dalam kualifikasi tinggi, 6 Guru (3.2\%) responden menyatakan bahwa kepuasan kerja yang dimiliki Guru terhadap kinerja berada dalam kualifikasi rendah, dan tidak ada responden yang menyatakan sangat rendah terkait kepuasan kerja yang dimiliki oleh Guru dalam kinerja. Kemudian nilai mean kepuasan kerja yaitu 170,61 berada pada interval 142-184 yang tergolong dalam kategori tinggi.

Berdasarkan hasil perhitungan selanjutnya mengenai kinerja Guru menunjukkan bahwa dari 185 responden, 50 Guru (27.0\%) responden menyatakan bahwa kinerja yang dimiliki oleh Guru berada dalam kualifikasi sangat tinggi, 131 Guru (70.8\%) responden menyatakan bahwa kinerja yang dimiliki Guru berada dalam kualifikasi tinggi, dan sebanyak 4 Guru (2.2\%) responden menyatakan bahwa kinerja yang dimiliki Guru berada dalam kualifikasi rendah, serta tidak ada responden yang menyatakan sangat rendah terkait kinerja yang dimiliki oleh Guru. Kemudian nilai mean kinerja yaitu 66,53 berada pada interval 55-71 yang tergolong dalam kategori tinggi.

Kepuasan kerja sifatnya mencolok pada kepribadian masing-masing. Sedangkan kinerja proses nyata yang menguntungkan baik kualitas maupun kuantitas pekerjaan sesuai tujuan dari sebuah organisasi. Dalam penelitian ini sebagian besar Guru memiliki kepuasan kerja dan kinerja yang tinggi. Dengan begitu guru akan merasa puas dengan kinerja yang telah diberikan dalam pekerjaannya selama ini.

\section{Hubungan antara Kompetensi dan Kinerja Guru di SMK Kota Batu}

Nilai Pearson Correlation sebesar 0,810 dan nilai signifikansi lebih kecil dari nilai probabilitas, sehingga memiliki hubungan positif dan signifikan antara kompetensi (X2) dengan kinerja (Y). Sejalan dengan hasil penelitian oleh Herman (2011) menunjukkan hasil ada pengaruh positif yang signifikan antara kompetensi profesional Guru terhadap Kinerja Guru sebesar 26,8\%. Penelitian lain oleh Wawan Wahyuddin (2016) mendapatkan hasil ada hubungan antara kompetensi guru dengan kinerja guru.

Dilihat dari hasil perhitungan menunjukkan bahwa dari 185 responden, 68 Guru (36.8\%) responden menyatakan bahwa kompetensi yang dimiliki oleh Guru terhadap kinerja berada dalam kualifikasi sangat tinggi, 117 Guru (63.2\%) responden menyatakan bahwa kepuasan kerja yang dimiliki Guru terhadap kinerja berada dalam kualifikasi tinggi, dan tidak ada responden yang menyatakan rendah dan sangat rendah terkait kompetensi yang dimiliki oleh Guru. Kemudian nilai mean kompetensi yaitu 177,70 berada pada interval 139-180 yang tergolong dalam kategori tinggi.

Berdasarkan hasil perhitungan selanjutnya mengenai kinerja Guru menunjukkan bahwa dari 185 responden, sebanyak 50 Guru (27.0\%) responden menyatakan bahwa kinerja yang dimiliki oleh Guru berada dalam kualifikasi sangat tinggi, 131 Guru (70.8\%) responden menyatakan bahwa kinerja yang dimiliki Guru berada dalam kualifikasi tinggi, dan sebanyak 4 Guru (2.2\%) responden menyatakan bahwa kinerja yang dimiliki Guru berada dalam kualifikasi rendah, serta tidak ada responden yang menyatakan sangat rendah terkait kinerja yang dimiliki oleh Guru. Kemudian nilai mean kinerja yaitu 66,53 berada pada interval 55-71 yang tergolong dalam kategori tinggi.

Kompetensi adalah keterampilan, kemampuan menyelesaikan tugas dan kemampuan fisik maksimal yang menunjukkan karakteristik seimbang. Menurut penelitian Robbins (2007), Kompetensi adalah perpaduan antara kemampuan berpikir dan kemampuan gerak tubuh yang memengaruhi besar kecilnya hasil seseorang dalam menyelesaikan berbagai tugas dalam satu waktu. Sedangkan kinerja atau prestasi kerja adalah proses nyata menguntungkan sebuah organisasi. Kompetensi yang tinggi berarti Guru 
telah mampu melaksanakan semua kompetensi yang telah distandarkan oleh Pemerintah sesuai dengan Peraturan Menteri Pendidikan Nasional Nomor 16 Tahun 2007. Sehingga kinerja yang dilakukan selama pekerjaannya juga dilakukan secara maksimal.

\section{Hubungan antara Kepuasan Kerja dan Kompetensi Guru di SMK Kota Batu}

Nilai Pearson Correlation sebesar 0,601 dan nilai signifikansi lebih kecil dari nilai probabilitas, sehingga $0,000<0,05$ berarti menunjukkan hubungan yang positif dan signifikan. Hal tersebut sejalan menurut ahli Mangkunegara (2004) juga memiliki pendapat mengenai faktor-faktor kepuasan kerja bisa juga dipengaruhi oleh faktor pegawai dan faktor pekerjaan.

Hasil perhitungan menunjukkan bahwa dari 185 responden, 42 Guru (22.7\%) responden menyatakan bahwa kepuasan kerja yang dimiliki oleh Guru terhadap kompetensi berada dalam kualifikasi sangat tinggi, 137 Guru (74.1\%) responden menyatakan bahwa kepuasan kerja yang dimiliki Guru terhadap kompetensi berada dalam kualifikasi tinggi, 6 Guru (3.2\%) responden menyatakan bahwa kepuasan kerja Guru terhadap kompetensi berada dikualifikasi rendah, dan tidak ada responden yang menyatakan sangat rendah terkait kepuasan kerja yang dimiliki oleh Guru dalam kompetensi. Kemudian nilai mean kepuasan kerja yaitu 170,61 berada pada interval 142-184 yang tergolong dalam kategori tinggi.

Kemudian membahas hasil perhitungan menunjukkan bahwa dari 185 responden, 68 Guru (36.8\%) responden menyatakan bahwa kompetensi yang dimiliki oleh Guru terhadap kepuasan kerja berada dalam kualifikasi sangat tinggi, 117 Guru (63.2\%) responden menyatakan bahwa kepuasan kerja yang dimiliki Guru terhadap kompetensi berada dalam kualifikasi tinggi, dan tidak ada responden yang menyatakan rendah dan sangat rendah terkait kompetensi yang dimiliki oleh Guru. Kemudian nilai mean kompetensi yaitu 177,70 berada pada interval 139-180 yang tergolong dalam kategori tinggi. Kepuasan kerja guru akan tinggi jika kompetensi yang dimiliki tinggi pula, karena akan berkaitan dengan kinerja yang dilakukan dalam kesehariannya. Sehingga ada keterkaitan antara ketiga variabel.

\section{Hubungan antara Kepuasan Kerja, Kompetensi, dan Kinerja Guru di SMK Kota Batu}

Nilai Standardized Coefficients Beta pada kepuasan kerja sebesar 0,195 dan kompetensi sebesar 0,693 menunjukkan terdapat hubungan yang positif. Perolehan nilai signifikansi 0,000 untuk variabel kepuasan kerja dan kompetensi, dapat diartikan ada hubungan signifikan pada variabel kepuasan kerja, kompetensi, dan kinerja guru di SMK Kota Batu. Kemudian nilai $R$ Square sebesar 0,680 membuktikan terdapat hubungan kuat antara kepuasan kerja, kompetensi, dan kinerja berdasarkan koefisien korelasi menurut Sugiyono (2007). Perolehan koefisien tersebut menunjukkan hubungan secara simultan memberikan sumbangan atau pengaruh sebesar $68 \%$, sedangkan $32 \%$ lainnya dipengaruhi oleh variabel selain prediktor.

Hasil temuan senada dengan penelitian H. Muhammad Arifin (2014) memperoleh hasil pengujian hipotesis yaitu ada pengaruh positif dan signifikan antara kompetensi terhadap kinerja guru, berarti jika kompetensi tinggi maka kinerja guru tinggi pula. Kemudian ada pengaruh positif dan signifikan antara kepuasan kerja dengan kinerja, yang artinya semakin tinggi kepuasan kerja maka akan semakin tinggi kinerja guru. Kinerja dari guru dapat dikatakan tinggi jika kepuasan kerja dan kompetensi yang dimiliki Guru juga tinggi, sehingga akan memiliki hubungan dalam menyelesaikan pekerjaan yang diemban dan melakukan kegiatan di lingkungan sekolah dalam menyelesaikan tugas secara efektif dan efisien dan maksimal. Peranan guru dalam mencerdaskan anak bangsa (siswa) dan memajukan sekolah dalam kancah pendidikan sangat penting bagi segala aspek yang berhubungan dengan dunia pendidikan. Hal tersebut dapat dicapai apabila guru memiliki kepuasan kerja dan kompetensi serta kinerja yang tinggi, sehingga guru akan mampu melaksanakan tugas sesuai dengan aturan pemerintah yang telah dibuat.

\section{KESIMPULAN}

Merujuk pada perolehan hasil penelitian yang ada serta pembahasan sehingga diperoleh kesimpulan diantaranya: (1) terdapat hubungan positif dan signifikan antara kepuasan kerja dan kinerja guru di SMK Kota Batu dengan Pearson Correlation sebesar 0,611 tergolong kuat. Sub variabel gaji atau upah 
yang diterima, hubungan kerja antarpribadi, jenis pekerjaan, ada kesempatan meningkatkan prestasi, kesempatan memperoleh penghargaan dan promosi, kondisi tempat kerja, fasilitas pendukung kerja, jaminan kesehatan dan keselamatan kerja, dan kenyamanan tempat kerja mempunyai nilai positif. Dalam hal ini berarti semakin tinggi kepuasan kerja maka semakin tinggi kualitas kinerja guru, (2) terdapat hubungan positif dan signifikan antara kompetensi dan kinerja guru di SMK Kota Batu dengan Pearson Correlation sebesar 0,810 yang tergolong sangat kuat. Sub variabel pedagogik, kepribadian, sosial, dan profesional mempunyai nilai positif. Dalam hal ini berarti semakin tinggi kompetensi maka semakin tinggi kualitas kinerja guru, (3) terdapat hubungan positif dan signifikan antara kepuasan kerja dan kompetensi guru di SMK Kota Batu dengan Pearson Correlation sebesar 0,601 tergolong kuat. Sub variabel gaji atau upah yang diterima, hubungan kerja antarpribadi, jenis pekerjaan, ada kesempatan meningkatkan prestasi, kesempatan memperoleh penghargaan dan promosi, kondisi tempat kerja, fasilitas pendukung kerja, jaminan kesehatan dan keselamatan kerja, dan kenyamanan tempat kerja mempunyai nilai positif. Dalam hal ini semakin tinggi kepuasan kerja maka semakin tinggi kualitas kinerja guru, (4) Terdapat hubungan positif signifikan dengan nilai Standardiezed Coefficient Beta sebesar 0,195 pada kepuasan kerja, dan sebesar 0,693 pada kompetensi. Koefisien determinan sebesar 0,680 berarti tingkat hubungan kuat antara kepuasan kerja, kompetensi dan kinerja guru di SMK Kota Batu. Hal tersebut dapat diartikan bahwasannya semakin tinggi tingkat kepuasan kerja dan kompetensi maka akan semakin tinggi pula kinerja Guru. Namun dalam penelitian ini nilai beta variabel kompetensi memberikan korelasi lebih besar dibandingkan dengan variabel kepuasan kerja.

\section{DAFTAR RUJUKAN}

Arifin, M. (2014, Mei). The Influence of Competence, Motivation, and Organisational Culture to High School Teacher Job Satisfaction and Performance. International Education Studies, 8(1): 43, (Online), dalam Canadian Center of Science and Education (http://www.ccsenet.org/journal/index.php/ies/article/viewFile/43874/2392).

Bafadal, I. 2003. Peningkatan Profesionalisme Guru Sekolah Dasar. Jakarta: Bumi Aksara.

Baroroh, S. (2013, Juli). Hubungan antara Kepuasan Kerja dengan Kinerja Karyawan, (online), http://www.google. co.id $/$ url? $\mathrm{sa}=\mathrm{t} \& \mathrm{rct}=\mathrm{j} \& \mathrm{q}=\& \mathrm{esrc}=\mathrm{s} \&$ source= $=\mathrm{web} \& \mathrm{~cd}=10 \& \mathrm{cad}=\mathrm{rja} \& u a c t=8 \& \mathrm{ved}=0 \mathrm{ahUKEwjw97-Pm} \mathrm{j} \mathrm{Y}$ AhVLNo8KHVHqAywQFghGMAk\&url=http\%3A\%2F\%2Feprints.ums.ac.id\%2F26721\%2F11\%2F02. NASKAH_PUBLIKASI.pdf\&usg=AOvVaw1EX7CsGpGBYrcaV9DyTbjE.

Bintariadi, B. (2010, Agustus). Prestasi Pendidikan Kota Batu Merosot karena Guru Sibuk Sertifikasi, (online), https://nasional.tempo.co/read/246897/prestasi-pendidikan-kota-batu-merosot-karena-guru-sibuk-sertifikasi.

Brahmasari, I. A. \& Suprayetno, A. (2008, Januari). Pengaruh Motivasi Kerja, Kepemimpinan dan Budaya Organisasi Terhadap Kepuasan Kerja Karyawan serta Dampaknya pada Kinerja Perusahaan (Studi kasus pada PT. Pei Hai International Wiratama Indonesia). Jurnal Manajemen dan Kewirausahaan, 10 (2): 128.

Burhanuddin, Imron, A., Maisyaroh. 2009. Manajemen Pendidikan. Karya Ilmiah, Proses dan Aplikasi di Sekolah. Malang: Universitas Negeri Malang.

Chamundeswari, S. (2013, Mei). Job Satisfaction and Performance of School Teachers. International Journal of Academic Research in Business and Scial Sciences, 3(5):hlm. 423, (Online), dalam HR MARS (Exploring Intellectual Capital) https://pdfs.semanticscholar.org/6b37/a469336c204008e56ad690aaf9d6b50414d7.pdf.

Handoko, H. T. 2000. Manajemen Personalia dan Sumberdaya Manusia, Edisi II, Cetakan Keempat Belas. Yogyakarta: BPFE.

Hasibuan, M. S. P. 2007. Manajemen Sumber Daya Manusia. Jakarta: Bumi Aksara.

Herman. (2011, Februari). Hubungan Kompetensi dengan Kinerja Guru Ekonomi SMA, (online), http://www. google.co.id/url?sa $=t \& r c t=j \& q=\&$ esrc $=$ s\&source $=$ web $\& c d=2 \& v e d=0$ ahUKEwiV7piNpvnYAhVJvI8KHU AEDB4QFggzMAE\&url=http\%3A\%2F\%2Ffe.um.ac.id\%2Fwp-content\%2Fuploads\%2F2009\%2F10\%2F3Herman.pdf\&usg=AOvVaw29h0hHAlIpXnJ0XATlfdtq.

Luthans, F. 2006. Perilaku Organisasi. Edisi 10 Jilid 1 dan 2, Terjemahan. Yogyakarta: Andi.

Mangkunegara, A. P. 2004. Manajemen Sumber Daya Manusia. Perusahaan Cetakan Pertama. Bandung: PT. Remaja Rosdakarya.

Mangkunegara, A. P. 2005. Evaluasi Kinerja Sumber Daya Manusia. Bandung: Refika Aditama.

Mangkunegara, A. P. 2009. Manajemen Sumber Daya Manusia. Bandung: PT. Remaja Rosdakarya. 
Peraturan Menteri Pendidikan Nasional Nomor 16 Tahun 2007. (2007, Januari). Standar Kualifikasi Akademik dan Kompetensi Guru, (online), http://www.google.co.id/url?sa=t\&rct=j\&q=\&esrc=s\&source=web\&cd $=1 \&$ ved=0ahUKEwiA4_yvmobTAhWBa7wKHbeXBFAQFggZMAA\&url=http\%3A\%2F\%2Fvervalsp. data.kemdikbud.go.id\%2Fprosespembelajaran\%2Ffile\%2FPermendiknas\%2520No\%252016\%2520Tah un\%25202007.pdf\&usg=AFQjCNF2kflNnL72tjoVJ2LycijlsrbADQ\&sig2=AnJZ8X8UPnaSs5Enuaz0Kw\& bvm=bv.151325232,d.dGc.

Robbins, S. P. 1996. Perilaku Organisasi, Konsep, Kontroversi dan Aplikasi. Alih Bahasa: Hadyana Pujaatmaka. Edisi Keenam. Jakarta: PT. Bhuana Ilmu Populer.

Robbins, S. P. 2003. Perilaku Organisasi, Jilid 2. Jakarta: PT. Indeks Kelompok Gramedia.

Robbins, S. P. 2007. Perilaku Organisasi. Indonesia: PT Macanan Jaya.

Robbins, S. P. \& Judge, T. A. 2007. Perilaku Organisasi. Jakarta: Salemba Empat.

Setyoningsih, L. (2015, Maret). Hubungan antara Kepuasan Kerja dengan Kinerja Guru di SMP Negeri 1 Ngemplak Boyolali, (online), http://eprints.ums.ac.id/37788/1/02.\%20Naskah\%20Publikasi.pdf.

Shadily, H.1992. Sosiologi untuk masyarakat Indonesia. Jakarta: Rineka Cipta.

Siagian, S. P. 2013. Manajemen Sumber Daya Manusia. Jakarta: PT. Bumi Aksara.

Sugiyono. 2007. Metode Penelitian Bisnis. Bandung: CV Alfabeta.

Tentama, F. (2015, Januari). Peran Kepuasan Kerja terhadap Kinerja pada Guru Pegawai Negeri Sipil (PNS) di Yogyakarta. Jurnal Psikologi Undip, 14(1): hlm.1-8, (online), dalam UNDIP https://ejournal.undip.ac.id/ index.php/psikologi/article/viewFile/9793/7852.

UU RI Nomor 14 Tahun 2005. (2005, Maret). Undang-Undang Republik Indonesia Nomor 14 Tahun 2005 tentang Guru dan Dosen, (online), http://www.google.co.id/url?sa=t\&rct=j\&q=\&esrc=s\&source=web\&cd=1\&ved= 0ahUKEwjCiOXpm4bTAhUITLwKHQekD68QFggZMAA\&url=http\%3A\%2F\%2Fsindikker.dikti.go.id\%2 Fdok\%2FUU\%2FUUNo142005\%28Guru\%2520\%26\%2520Dosen\%29.pdf\&usg=AFQjCNH_QsClU4JNK kGbxLFMhw4d2sM9tA\&sig2=FmlxPe3YqHYvdmYIOVe8OA\&bvm=bv.151325232,d.dGc.

Wahyuddin, W. (2016, Mei). The Relationship between of Teacher Competence, Emotional Intelligence and Teacher Performance Madrasah Tsanawiyah at District of Serang Banten. Higher Education Studies, 6(1): hlm. 128-135, (Online), dalam Canadian Center of Science and Education (https://files.eric.ed.gov/fulltext/ EJ1099398.pdf). 